\title{
One-year follow-up of neurological status of patients after cardiac arrest seen at the emergency room of a teaching hospital
}

\section{Um ano de seguimento da condição neurológica de pacientes pós-parada cardiorrespiratória atendidos no pronto-socorro de um hospital universitário}

\author{
Cássia Regina Vancini-Campanharo ${ }^{1}$, Rodrigo Luiz Vancini², Claudio Andre Barbosa de Lira ${ }^{3}$, \\ Maria Carolina Barbosa Teixeira Lopes ${ }^{1}$, Meiry Fernanda Pinto Okuno ${ }^{1}$, Ruth Ester Assayag Batista ${ }^{1}$, \\ Álvaro Nagib Atallah ${ }^{4}$, Aécio Flávio Teixeira de Góis ${ }^{4}$
}

\begin{abstract}
Objective: To describe neurological status and associated factors of survivors after cardiac arrest, upon discharge, and at 6 and 12 month follow-up. Methods: A cohort, prospective, descriptive study conducted in an emergency room. Patients who suffered cardiac arrest and survived were included. A one-year consecutive sample, comprising 285 patients and survivors $(n=16)$ followed up for one year after discharge. Neurological status was assessed by the Cerebral Performance Category before the cardiac arrest, upon discharge, and at 6 and 12 months after discharge. The following factors were investigated: comorbidities, presence of consciousness upon admission, previous cardiac arrest, witnessed cardiac arrest, location, cause and initial rhythm of cardiac arrest, number of cardiac arrests, interval between collapse and start of cardiopulmonary resuscitation, and between collapse and end of cardiopulmonary resuscitation, and duration of cardiopulmonary resuscitation. Results: Of the patients treated, $4.5 \%(n=13)$ survived after 6 and 12 months follow-up. Upon discharge, $50 \%$ of patients remained with previous Cerebral Performance Category of the cardiac arrest and $50 \%$ had worsening of Cerebral Performance Category. After 6 months, 53.8\% remained in the same Cerebral Performance Category and $46.2 \%$ improved as compared to discharge. After 12 months, all patients remained in the same Cerebral Performance Category of the previous 6 months. There was no statistically significant association between neurological outcome during follow-up and the variables
\end{abstract}

assessed. Conclusion: There was neurological worsening at discharge but improvement or stabilization in the course of a year. There was no association between Cerebral Performance Category and the variables assessed.

Keywords: Heart arrest; Cardiopulmonary resuscitation; Neurologic manifestations; Glasgow coma scale; Brain diseases

\section{RESUMO}

Objetivo: Identificar a condição neurológica e os fatores associados de sobreviventes pós-parada cardiorrespiratória na alta hospitalar, após 6 e 12 meses de seguimento. Métodos: Estudo de coorte, prospectivo e descritivo, realizado em um pronto-socorro. Foram incluídos pacientes em parada cardiorrespiratória que sobreviveram à alta. A amostra foi consecutiva por um ano, sendo composta por 285 pacientes, e os sobreviventes $(n=16)$ foram acompanhados por um ano após alta. 0 estado neurológico foi avaliado pela Categoria de Performance Cerebral antes da parada, na alta, 6 e 12 meses após alta. Foram investigados os seguintes fatores: comorbidades, presença de consciência na admissão, parada cardiorrespiratória prévia, parada cardiorrespiratória testemunhada, local, causa e ritmo inicial da parada, número de paradas, intervalo entre colapso e início da ressuscitação cardiopulmonar, e entre colapso e término da ressuscitação, e duração

\footnotetext{
'Escola Paulista de Enfermagem, Universidade Federal de São Paulo, São Paulo, SP, Brazil.

${ }^{2}$ Centro de Educação Física e Desportos, Universidade Federal do Espírito Santo, Vitória, ES, Brazil.

${ }^{3}$ Human Physiology and Exercise Department, Faculdade de Educação Física e Dança, Universidade Federal de Goiás, Goiânia, GO, Brazil.

${ }^{4}$ Escola Paulista de Medicina, Universidade Federal de São Paulo, São Paulo, SP, Brazil.

Corresponding author: Cássia Regina Vancini-Campanharo - Escola Paulista de Enfermagem, Universidade Federal de São Paulo - Rua Napoleão de Barros, 754, 2nd floor - Vila Clementino Zip code: 04024-002 - São Paulo, SP, Brazil - Phone: (55 11) 5576 4430, branch line: 1611 - E-mail: cvancini@unifesp.br

Received on: Oct 30, 2014 - Accepted on: Apr 4, 2015

Conflict of interest: none
}

DOI: 10.1590/S1679-45082015A03286 
da ressuscitação. Resultados: Dos pacientes atendidos, 4,5\% $(n=13)$ sobreviveram após 6 e 12 meses de seguimento. Na alta, 50\% dos pacientes permaneceram com Categoria de Performance Cerebral prévia à parada, e 50\% tiveram piora da mesma. Após 6 meses, 53,8\% permaneceram com mesma Categoria de Performance Cerebral, e 46,2\% tiveram melhora em relação à alta. Após 12 meses, a totalidade dos pacientes permaneceu com mesma Categoria de Performance Cerebral em relação aos 6 meses anteriores. Não houve associação estatisticamente significativa entre evolução neurológica durante 0 seguimento e variáveis de interesse. Conclusão: Observou-se piora neurológica na alta, mas houve melhora ou estabilização no decorrer de 1 ano. Não foi encontrada associação entre Categoria de Performance Cerebral e variáveis de interesse.

Descritores: Parada cardíaca; Ressuscitação cardiopulmonar; Manifestações neurológicas; Escala de coma de Glasgow; Encefalopatias

\section{INTRODUCTION}

Each year it is estimated that approximately 359,400 individuals are admitted with cardiac arrest in emergency rooms in the United States. ${ }^{(1)}$

In Brazil, there are 200,000 cases of cardiac arrest each year, half of them in hospital environment.(2) The discharge survival rates range from $9.5 \%$ for outof-hospital cardiac arrest cases, and $24.2 \%$ for inhospital cases. Of the survivors, 40 to $50 \%$ remain with cognitive impairments, such as memory and intellectual performance deficits. ${ }^{(1)}$

The post-cardiac arrest brain injury, also called "post-cardiac arrest syndrome," is related to a complex pathophysiological process of ischemia/reperfusioninjury. (2,3) During cardiac arrest, the lack of brain oxygenation results in low production of adenosine triphosphate (ATP), loss of cellular membrane integrity and release of glutamate into the extracellular environment, which activates N-methyl-D-aspartate (NMDA) receptors, resulting in the opening of calcium channels, with inflow of calcium ions into the intracellular environment. The increase in intracellular calcium concentrations promotes excitotoxicity, with release of cytochrome p450 and consequent mitochondrial apoptosis, also causing changes in the cellular deoxyribonucleic acid (DNA). ${ }^{(4)}$

During reperfusion, the excitotoxicity may be reduced by the oxygen supplied as a substrate for various enzymatic reactions which, in turn, produce free radicals that cause lipid peroxidation, protein oxidation and DNA fragmentation, all of which contribute to cell injury or death. The cell injury starts with the ischemia and reperfusion but can last for hours or days after the initial injury. ${ }^{(4)}$ The neurological injuries caused by this pathophysiological process, and their clinical manifestations, vary according to the affected brain region. In severe cases, the patient may present a persistent comatose state, and these individuals often develop cognitive impairments, becoming completely dependent; others minimally regain consciousness or remain in a vegetative state; and few come out of coma neurologically intact..$^{(5)}$

The financial implications for the care of people in a vegetative state or with cognitive impairment are substantial. The health system and the family members are burdened with considerable expenses related to temporary or permanent home care. ${ }^{(5)}$

In this context, strategies to assess the neurological prognosis of cardiac arrest survivors are of interest. Traditionally, the prognosis is determined by algorithms, which deal with clinical and other auxiliary resources. Variables such as old age, non-witnessed cardiac arrest, no cardiopulmonary resuscitation (CPR) or prolonged $\mathrm{CPR}$, initial cardiac rhythm in cardiac arrest and elevated body temperature in the post-CPR period are associated with unfavorable prognosis, but they cannot accurately differentiate patients with good or poor neurological outcome. A thorough neurological evaluation, electrophysiological studies, measurement of biochemical markers and imaging studies may also assist in obtaining this information. ${ }^{(5,6)}$

Therefore, a study to assess the neurological status of patients after cardiac arrest may contribute to the development of prognostic strategies for these patients and thus reduce patient treatment costs.

\section{OBJECTIVE}

To identify the neurological status and its associated factors in post-cardiac arrest survivors upon discharge, after 6 and 12 months of follow-up.

\section{METHODS}

This was a cohort, prospective and descriptive study conducted in the emergency room of the Hospital São Paulo, in São Paulo (SP). The study population consisted of patients seen at the emergency room with a diagnosis of cardiac arrest and who survived to hospital discharge. Exclusion criteria were post-cardiac arrest survivors seen in other sectors of the Hospital São Paulo.

The sample was obtained consecutively, consisting of 285 patients found in cardiac arrest, with a mean age of $66.3 \pm 17.2$ (17-101 years) years, of whom $55.8 \%$ 
$(n=159)$ were men and $71.9 \%(n=205)$ were white. Of the total patients found in cardiac arrest, 39.6\% $(\mathrm{n}=113)$ had return of spontaneous circulation, $18.6 \%$ $(n=53)$ survived the first 24 hours, 5.6\% $(n=16)$ were discharged from hospital, and $4.5 \%(n=13)$ were alive after 6 month and 1 year follow-ups. For the purposes of this study, only the 16 patients who were discharged from hospital were evaluated, of whom 3 patients died in the first 6 month follow-up, and the remainder $(n=13)$ were monitored for 1 year after the event. Figure 1 shows the flowchart outlining the follow-up of the patients.

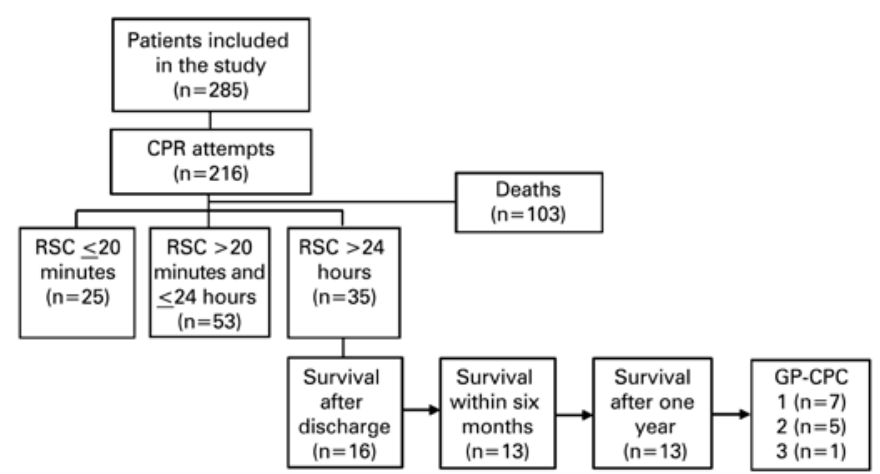

CPR: cardiopulmonary resuscitation; RSC: return of spontaneous circulation; GP-CPC: Glasgow-Pittsburgh Cerebral Performance Category.

Figure 1. Flowchart of the study patients follow-up

Data were collected from February 2011 to January 2012, by trained nurses, using the standard report for collecting meaningful data on cardiac arrest, the InHospital Utstein-Style. ${ }^{(7)}$

The report included the following variables: age; sex and skin color of the patient; previous cardiac arrest and neurological status of the patient before the current cardiac arrest; cardiac arrest location; if the cardiac arrest was witnessed; presumed immediate cause and initial rhythm in cardiac arrest; basic and advanced life support procedures carried out during the emergency care; interval between start of CPR and the first shock; interval between start of CPR and the placement of an advanced airway; interval between start of CPR and the first dose of epinephrine; interval between start and end of CPR; return of spontaneous circulation or death and, in survivors, the neurological status.

The neurological status was evaluated with the patient, family or guardians, at hospital discharge, after 6 month and 1 year follow-ups, using the GlasgowPittsburgh Cerebral Performance Category (GP-CPC), ${ }^{(7)}$ which is divided into five categories. Category 1 indicates complete independence and working ability; Category 2 indicates moderate disability, ability to work part-time and independence for the Activities of Daily Life; Category 3 indicates severe disability and total dependence for the Activities of Daily Life; Category 4 indicates a persistent vegetative state; and Category 5 indicates brain death. To evaluate the clinical course of GP-CPC, we used the following parameters: improved, no change, or worse over time.

Besides the above variables, we evaluated the patients' consciousness, breathing and pulse upon admission, and the number of cardiac arrests experienced by each patient.

For statistical analysis, we considered variables that could interfere with the neurological status of the patient after the return of spontaneous circulation. ${ }^{(2)}$ These were: previous medical history, consciousness on admission, previous occurrence of cardiac arrest, cardiac arrest location, if the cardiac arrest was witnessed, presumed immediate cause of cardiac arrest, initial rhythm in cardiac arrest, number of cardiac arrests experienced by the patient, interval between collapse and start of CPR, and interval between start and end of CPR.

Variables were stored in Excel spreadsheets, version Microsoft Office Excel 2003, for later statistical analysis. Statistical analysis was performed using the Statistical Package for Social Science (SPSS), version 19 (Chicago, Il, USA). Data were presented by descriptive statistics. For continuous variables, the mean, standard deviation, median, minimum and maximum of the data were calculated. For categorical variables, frequency and percentage were calculated. If the patient had more than one cardiac arrest, the first event was taken into account in the analysis.

To compare the clinical course of GP-CPC with the categorical variables of interest, we used the Fisher's exact test. To compare the clinical course of GP-CPC with the continuous variables of interest, we used the Mann-Whitney test. The level of significance was 5\% $(\mathrm{p}<0.05)$.

This study was approved by the Ethics Committee of the Universidade Federal de São Paulo (protocol 0030/2011). The survivors were included in the study after reading and signing the Informed Consent Agreement. All procedures were performed according to the Helsinki Declaration and the Resolution 466/12 of the National Health Council/Ministry of Health.

\section{RESULTS}

The neurological status and the clinical course of the patients are shown in tables 1 and 2, respectively. 
Table 1. Neurological status evaluated using the Glasgow-Pittsburgh Cerebral Performance Category

\begin{tabular}{lcccc}
\hline GP-CPC & $\begin{array}{c}\text { Pre-CA } \\
\mathbf{n}(\%)\end{array}$ & $\begin{array}{c}\text { Upon discharge } \\
\mathbf{n}(\%)\end{array}$ & $\begin{array}{c}\text { After } \mathbf{6} \text { months } \\
\mathbf{n}(\%)\end{array}$ & $\begin{array}{c}\text { After } \mathbf{1} \text { year } \\
\mathbf{n}(\%)\end{array}$ \\
\hline 1 & $8(50)$ & $3(18.8)$ & $7(53.8)$ & $7(53.8)$ \\
2 & $8(50)$ & $10(62.5)$ & $5(38.5)$ & $5(38.5)$ \\
3 & - & $2(12.5)$ & $1(7.7)$ & $1(7.7)$ \\
4 and 5 & - & $1(6.3)$ & - & - \\
\hline Total $n(100 \%)$ & 16 & 16 & 13 & 13 \\
\hline
\end{tabular}

Table 2. Clinical course of the neurological status evaluated using the GlasgowPittsburgh Cerebral Performance Category

\begin{tabular}{lccc}
\hline GP-CPC & $\begin{array}{c}\text { Pre-CA to discharge } \\
\mathbf{n}(\%)\end{array}$ & $\begin{array}{c}\text { From discharge } \\
\text { to } \mathbf{6} \text { months } \\
\mathbf{n ~ ( \% )}\end{array}$ & $\begin{array}{c}\text { From } \mathbf{6} \text { months } \\
\text { to } \mathbf{1} \text { year } \\
\mathbf{n}(\%)\end{array}$ \\
\hline Improved & $1(6.3)$ & $6(46.2)$ & - \\
No change & $8(50)$ & $7(53.8)$ & $13(100)$ \\
Worse & $7(43.8)$ & - & - \\
\hline Total n $(100 \%)$ & 16 & 13 & 13 \\
\hline CA: cardiac arrest; GP-CPC: Glasgow-Pittsburgh Cerebral Performance Category. &
\end{tabular}

Before cardiac arrest, half of the patients had GPCPC 1, and the other half had GP-CPC 2. At hospital discharge, most patients (62.5\%) had GP-CPC 2, and after 6 month and 1-year follow-up, 53.8\% had GP-CPC 1.

Of the survivals at discharge $(n=16), 6.3 \%$ had improved GP-CPC, $50 \%$ remained with the same GPCPC, and $43.8 \%$ had worse GP-CPC, compared to the previous neurological status. After 6 month follow-up, $53.8 \%$ remained with the same GP-CPC, and $46.2 \%$ had improved GP-CPC, compared to their categories at discharge. After 1-year follow-up, all patients remained with the same GP-CPC they had in the previous 6 months.

According to table 3, when comparing the clinical course of GP-CPC previous to cardiac arrest, at hospital discharge and at 1 year follow-up with the variables of interest, there was no statistically significant difference.

Table 3. Clinical course of the neurological status evaluated using the GlasgowPittsburgh Cerebral Performance Category compared to the variables of interest (\%)

\begin{tabular}{|c|c|c|c|c|c|c|}
\hline \multirow{2}{*}{ Variables } & \multicolumn{3}{|c|}{$\begin{array}{c}\text { Pre-CA GP-CPC until } \\
\text { discharge }(n=16)\end{array}$} & \multicolumn{3}{|c|}{$\begin{array}{l}\text { From discharge to } \\
1 \text { months }(n=13)\end{array}$} \\
\hline & $\begin{array}{l}\text { Improved/ } \\
\text { no change }\end{array}$ & Worse & $\mathrm{p}$ value & Improved & Worse & p value \\
\hline \multicolumn{7}{|c|}{ Previous medical history } \\
\hline No & - & 100 & - & 100 & - & - \\
\hline Yes & 64.3 & 35.7 & & 36.4 & 63.6 & \\
\hline Total & 9 & 7 & & 6 & 7 & \\
\hline
\end{tabular}

...Continuation

Table 3. Clinical course of the neurological status evaluated using the Glasgow Pittsburgh Cerebral Performance Category compared to the variables of interest (\%)

\begin{tabular}{lcccccc}
\hline \multirow{2}{*}{ Variables } & \multicolumn{2}{c}{$\begin{array}{c}\text { Pre-CA GP-CPC until } \\
\text { discharge }(\mathbf{n = 1 6})\end{array}$} & $\begin{array}{c}\text { From discharge to } \\
\mathbf{1} \text { months } \mathbf{( n = 1 3 )}\end{array}$ \\
\cline { 2 - 6 } & $\begin{array}{l}\text { Improved/ } \\
\text { no change }\end{array}$ & Worse & $\mathbf{p}$ value & Improved Worse p value \\
\hline $\begin{array}{l}\text { Conscious on admission } \\
\text { Yes }\end{array}$ & 69.2 & 30.8 & 0.0625 & 30 & 70 & 0.0699 \\
No & - & 100 & & 100 & - & \\
Total & 9 & 7 & & 6 & 7 & \\
Previous CA & & & & & - \\
Yes & 50 & 50 & 1.0000 & - & - \\
No & 58.3 & 41.7 & - & - \\
Total & 9 & 7 & & - & -
\end{tabular}

Event location

Out-of-hospital

In-hospital

Total

Witnessed

Yes

Total

Immediate cause

Fatal arrhythmia

Hypotension

Respiratory failure

Metabolic changes

Ischemia or AMI

Total

Initial rhythm

\begin{tabular}{|c|c|c|c|c|c|c|}
\hline Out-of-hospital & - & 100 & - & 100 & - & - \\
\hline In-hospital & 60 & 40 & & 41.7 & 58.3 & \\
\hline Total & 9 & 7 & & 6 & 7 & \\
\hline \multicolumn{7}{|l|}{ Nitnessed } \\
\hline Yes & 56.3 & 43.8 & - & 46.2 & 53.8 & - \\
\hline Total & 9 & 7 & & 6 & 7 & \\
\hline \multicolumn{7}{|l|}{ mmediate cause } \\
\hline Fatal arrhythmia & 33.3 & 66.7 & - & 50 & 50 & - \\
\hline Hypotension & 100 & - & & - & 100 & \\
\hline Respiratory failure & 50 & 50 & & 50 & 50 & \\
\hline Metabolic changes & 100 & - & & - & - & \\
\hline Ischemia or AMI & 50 & 50 & & 57.1 & 42.9 & \\
\hline Total & 9 & 7 & & 6 & 7 & \\
\hline \multicolumn{7}{|l|}{ nitial rhythm } \\
\hline VF & 83.3 & 16.7 & 0.3329 & 20 & 80 & 0.4884 \\
\hline PEA & 44.4 & 55.6 & & 57.1 & 42.9 & \\
\hline Total & 9 & 6 & & 5 & 7 & \\
\hline \multicolumn{7}{|l|}{ Number of CA } \\
\hline Median (min-max) & $1(1-2)$ & $1(1-2)$ & 0.3901 & $1(1-2)$ & $1(1-2)$ & 0.9093 \\
\hline Total & 9 & 7 & & 6 & 7 & \\
\hline
\end{tabular}

Number of CA

Median (min-max

Total

Interval between

collapse-start of CPR

Median (min-max)

Total

nterval between start of

CPR-end of CPR

\begin{tabular}{lcccccc} 
Median (min-max) & $6(2-15)$ & $5(2-12)$ & 0.6697 & $6(2-12)$ & $6(2-15)$ & 1.0000 \\
\hline Total & 9 & 7 & 6 & 7 &
\end{tabular}

Data analysis using Fisher's exact test and Mann-Whitney test, with $p<0.05$.

GP-CPC: Glasgow-Pittsburgh Cerebral Performance Category: CA: cardiac arrest; AMI: acute myocardial infarction; VF: ventricular fibrillation; PEA: pulseless electric activity; CPR: cardiopulmonary resuscitation.

\section{DISCUSSION}

Brain injury is a major cause of morbidity and mortality after a cardiac arrest. The identification of its pathophysiological mechanisms and its relationship with patient characteristics and CPR maneuvers can improve the prognosis for these patients. ${ }^{(8)}$

The reason we emphasize the possibility of poor neurologic outcomes is to point out the importance of 
establishing measures at various levels of care, from intensive care to palliative measures. Thus, adequate prognostic tests can prevent the occurrence of false results to identify a poor prognosis. ${ }^{(5)}$

In this study, of the 285 patients found in cardiac arrest, $5.6 \%(\mathrm{n}=16)$ had hospital discharge, and $4.5 \%$ $(\mathrm{n}=13)$ were alive after 6 month and 1-year follow-up. Of the survivors at discharge $(\mathrm{n}=16), 56.3 \%$ showed improvement or maintained the GP-CPC before the event; the remainder had worse GP-CPC. After 6 months of follow-up, 53.8\% remained with the same GP-CPC, and $46.2 \%$ had improved GP-CPC compared to their categories at discharge. After 1 year of followup, all patients remained with the same GP-CPC they had in the previous 6 months.

In this study, when comparing the clinical course of GP-CPC previous to cardiac arrest, at hospital discharge and at 1 year follow-up with the variables of interest, there was no statistically significant difference. However, the $\mathrm{p}$ values for consciousness on admission were 0.0625 for the clinical course of pre-cardiac arrest GP-CPC until discharge, and 0.0699 for the clinical course of GP-CPC from discharge to 1-year follow-up these values are close to the statistical significance. This finding suggests that conscious patients on admission, who therefore suffered in-hospital cardiac arrest and were treated earlier, may have a better chance of recovery. ${ }^{(9)}$

Literature data point to some critical factors that can interfere with post-cardiac arrest GP-CPC, such as the interval from collapse to start of CPR maneuvers, if the cardiac arrest was witnessed, the initial rhythm in the cardiac arrest, ventricular fibrillation or pulseless ventricular tachycardia, and early access to advanced life support maneuvers. ${ }^{(10,11)}$ A study conducted in Thailand, aiming to identify factors associated with post-cardiac arrest survival, revealed that the return of spontaneous circulation rates were associated to the neurological status of the patient previous to cardiac arrest. Patients with GP-CPC 1 and 2 had 10.8 times greater probability of presenting a return of spontaneous circulation. ${ }^{(12)}$

In Brazil, studies have been conducted to identify clinical predictors of post-cardiac arrest survival, showing that a good neurological outcome (GP-CPC 1 and 2) was significantly associated with no previous diseases, witnessed cardiac arrest, ventricular fibrillation or pulseless ventricular tachycardia as the initial rhythm in cardiac arrest, CPR and defibrillation maneuvers carried out before the arrival of the advanced life support unit, shorter interval between collapse and start of CPR maneuvers. ${ }^{(10,13)}$
Most studies on post-cardiac arrest survival predictors aimed to reliably forecasting a better outcome than a vegetative state or persistent severe disability and total dependence in the period of 3-6 months after the event. Numerous studies tested treatments directed at specific cascade stages of the systemic injury and failed to show a benefit. ${ }^{(14)}$

A recent concept is the post-cardiac arrest care, which has been regarded as the fifth survival chain link ${ }^{(2)}$ and can potentially improve early mortality caused by hemodynamic instability and failure of multiple organs and systems; and morbidity and late mortality, resulting from neurological injury. ${ }^{(15)}$ The main measures to be adopted include: early reperfusion treatment for coronary thrombosis cases; stabilization and maintenance of hemodynamic parameters; correction of blood gas disturbances; maintenance of normal glucose, hemoglobin, and electrolytes values; control of water balance; introduction of early enteral nutrition, sedation and analgesia; prevention and treatment of seizures; inducing therapeutic hypothermia; and determining the patient's prognosis. ${ }^{(3,15)}$

Another therapeutic modality that has shown benefits for post-cardiac arrest survivors with some degree of neurological impairment is neurological rehabilitation, ${ }^{(16)}$ consisting of the repetition of certain activities, in order to facilitate the neuronal plasticity process. ${ }^{(17-20)}$ Whereas rehabilitation decreases the burden of care required of the family and society, there are gaps in the literature regarding this aspect. ${ }^{(8)}$

Better studies to confirm poor neurological outcomes of predictive indicators should have an adequate number of patients and be conducted at least three days after the event, during which consciousness and motor responses return, and take into account confounding factors, such as the use of therapeutic hypothermia an intervention whose influence on the measurement of prognostic variables has not been clarified yet. ${ }^{(20)}$

\section{CONCLUSION}

We were unable to establish a statistically significant association between the clinical course of the GlasgowPittsburgh Cerebral Performance Category during the follow-up, and previous medical history, consciousness on admission, previous occurrence of cardiac arrest, cardiac arrest location, if the cardiac arrest was witnessed, presumed immediate cause and initial rhythm in cardiac arrest, number of cardiac arrests experienced by the patient, the interval between collapse and start of cardiopulmonary resuscitation, and duration of cardiopulmonary resuscitation. The variable consciousness on admission was the closest to the statistical significance. 
The Glasgow-Pittsburgh Cerebral Performance Category can be used to assess the neurologic outcome after cardiac arrest, but it is a comprehensive scale, which does not reflect the neurological status in a complete manner. The forecast of an accurate neurological outcome for comatose patients after cardiac arrest is essential to guide actions at all levels of care and end-of-life decisions.

\section{REFERENCES}

1. Go AS, Mozaffarian D, Roger VL, Benjamin EJ, Berry JD, Borden WB, Bravata DM, Dai S, Ford ES, Fox CS, Franco S, Fullerton HJ, Gillespie C, Hailpern SM, Heit JA, Howard VJ, Huffman MD, Kissela BM, Kittner SJ, Lackland DT, Lichtman JH, Lisabeth LD, Magid D, Marcus GM, Marelli A, Matchar DB, McGuire DK, Mohler ER, Moy CS, Mussolino ME, Nichol G, Paynter NP, Schreiner PJ, Sorlie PD, Stein J, Turan TN, Virani SS, Wong ND, Woo D, Turner MB; American Heart Association Statistics Committee and Stroke Statistics Subcommittee. Heart disease and stroke statistics--2013 update: a report from the American Heart Association. Circulation. 2013;127(1):e6-e245. Review. Erratum in: Circulation. 2013;127(23):e841. Circulation. 2013;127(1).

2. Gonzalez MM, Timerman S, Gianotto-Oliveira R, Polastri TF, Canesin MF, Schimidt A, Siqueira AW, Pispico A, Longo A, Pieri A, Reis A, Tanaka AC, Santos AM, Quilici AP, Ribeiro AC, Barreto AC, Pazin-Filho A, Timerman A, Machado $\mathrm{CA}$, Franchin Neto C, Miranda CH, Medeiros CR, Malaque CM, Bernoche C, Gonçalves DM, Sant'Ana DG, Osawa EA, Peixoto E, Arfelli E, Evaristo EF, Azeka E, Gomes EP, Wen FH, Ferreira FG, Lima FG, Mattos FR, Galas FG, Marques FR, Tarasoutchi F, Mancuso FJ, Freitas GR, Feitosa-Filho GS, Barbosa GC, Giovanini GR, Miotto HC, Guimarães HP, Andrade JP, Oliveira-Filho J, Fernandes JG, Moraes Junior JB, Carvalho JJ, Ramires JA, Cavalini JF, Teles JM, Lopes JL, Lopes LN, Piegas LS, Hajjar LA, Brunório L, Dallan LA, Cardoso LF, Rabelo MM, Almeida MF, Souza MF, Favarato MH, Pavão ML, Shimoda MS, Oliveira Junior MT, Miura N, Filgueiras Filho NM, Pontes-Neto OM, Pinheiro PA, Farsky OS, Lopes RD, Silva RC, Kalil Filho R, Gonçalves RM, Gagliardi RJ, Guinsburg R, Lisak S, Araújo S, Martins SC, Lage SG, Franchi SM, Shimoda T, Accorsi TD, Barral TC, Machado TA, Scudeler TL, Lima VC, Guimarães VA, Sallai VS, Xavier WS, Nazima W, Sako YK; Sociedade Brasileira de Cardiologia. [First guidelines of the Brazilian Society of Cardiology on Cardiopulmonary Resuscitation and Cardiovascular Emergency Care]. Arq Bras Cardiol. 2013;101 (2 Suppl 3):1-221. Portuguese.

3. Popp E, Bottiger BW. Cerebral resuscitation: state of the art, experimental approaches and clinical perspectives. Neurol Clin. 2006;24(1):73-87, vi. Review.

4. Geocadin RG, Koenig MA, Jia X, Stevens RD, Peberdy MA. Management of brain injury after resuscitation from cardiac arrest. Neurol Clin. 2008;26(2): 487-506. Review.

5. Wijdicks EF, Hijdra A, Young GB, Bassetti CL, Wiebe S; Quality Standards Subcommittee of the American Academy of Neurology. Practice parameter: prediction of outcome in comatose survivors after cardiopulmonary resuscitation (an evidence-based review): report of the Quality Standards Subcommittee of the American Academy of Neurology. Neurology. 2006;67(2):203-10. Review.
6. Wachelder EM, Moulaert VR, van Heugten C, Verbunt JA, Bekkers SC, Wade DT. Life after survival: long-term daily functioning and quality of life after an outof-hospital cardiac arrest. Resuscitation. 2009;80(5):517-22.

7. Avansi Pdo A, Meneghin P. [Translation and adaptation of the In-Hospital Utstein style into the Portuguese language]. Rev Esc Enferm USP. 2008;42(3):504-11. Portuguese.

8. Cassiani-Miranda CA, Pérez-Aníbal E, Vargas-Hernández MC, Castro-Reyes ED, Osorio AF. Lesión cerebral posterior a paro cardiorrespiratorio. Acta Neurol Colomb. 2013;29(4):255-65.

9. Jones DA, DeVita M, Bellomo R. Rapid-response teams. N Engl J Med. 2011; 365(2):139-46. Review.

10. Morais DA. Ressuscitação cardiopulmonar pré-hospitalar: fatores determinantes da sobrevida [tese]. Belo Horizonte (MG): Escola de Enfermagem da Universidade Federal de Minas Gerais; 2012.

11. Corrêa AR, Carvalho DV, Morais DA. Características dos atendimentos a vítimas de parada cardíaca extra-hospitalar. Rev Enferm UFPE on line. 2013: 7(11):6382-90.

12. Sittichanbuncha Y, Prachanukool T, Sawanyawisuth K. A 6-year experience of CPR outcomes in an emergency department in Thailand. Ther Clin Risk Manag. 2013;9:377-81

13. Semensato G, Zimerman L, Rohde LE. Initial evaluation of the Mobile Emergency Medical Services in the city of Porto Alegre, Brazil. Arq Bras Cardiol. 2011;96(3):196-204.

14. Pfeifer $R$, Börner $A$, Krack A, Sigusch $H H$, Surber R, Figulla HR. Outcome after cardiac arrest: predictive values and limitations of the neuroproteins neuronspecific enolase and protein S-100 and the Glasgow Coma Scale. Resuscitation. 2005;65(1):49-55.

15. Peberdy MA, Callaway CW, Neumar RW, Geocadin RG, Zimmerman JL, Donnino M, Gabrielli A, Silvers SM, Zaritsky AL, Merchant R, Vanden Hoek TL, Kronick SL; American Heart Association. Part 9: post- cardiac arrest care: 2010 American Heart Association Guidelines for Cardiopulmonary Resuscitation and Emergency Cardiovascular Care. Circulation. 2010;122(18 Suppl3):S768-86. Review. Erratum in: Circulation. 2011;123(6):e237. Circulation. 2011;124(15):e403.

16. Kurihara M, Ogasawara S, Kadowaki A, Onizuka S, Samejima M. [Consideration of early rehabilitation in the treatment of post-cardiac arrest syndrome]. Nihon Rinsho. 2011;69(4):653-7. Japanese.

17. Dimyan MA, Dobkin BH, Cohen LG. Emerging subspecialties: neurorehabilitation: training neurologists to retrain the brain. Neurology. 2008;70(16):e52-4. Review.

18. Fertl E, Vass K, Sterz F, Gabriel H, Auff E. Neurological rehabilitation of severely disabled cardiac arrest survivors. Part I. Course of post-acute inpatient treatment. Resuscitation. 2000;47(3):231-9.

19. Howell K, Grill E, Klein AM, Straube A, Bender A. Rehabilitation outcome of anoxic-ischaemic encephalopathy survivors with prolonged disorders of consciousness. Resuscitation. 2013;84(10):1409-15.

20. Al Thenayan E, Savard M, Sharpe M, Norton L, Young B. Predictors of poor neurologic outcome after induced mild hypothermia following cardiac arrest. Neurology. 2008;71(19):1535-7. 